\title{
Changing Transitions from Early Childhood Education to Primary Education in Finland
}

\author{
Jonna Kangas \\ University of Helsinki \\ jonna.kangas@helsinki.fi \\ Tuulikki Ukkonen-Mikkola
University of Jyväskylä
tuulikki.t.ukkonen-mikkola@jyu.fi
}

Finnish early childhood education (ECE) policy has been undergoing a reformation since 2013 under the guidance of the Ministry of Education and Culture and as part of the educational system. Thus, the pedagogical significance in the educational policies has been emphasised more than before. The most recent reform, beginning August 2021, starts introduces two-year pre-primary education. Through this the transition process from ECE to primary education in Finland is extended to cover four years of children's lives from 5 to 8 years. In this study we consider the transition process from the perspectives of teacher education and qualifications, organisational and working cultures, learning environment, implementation of curriculum, and assessment and evaluation. We address the view that the threat of schoolification, and test-driven education lingers above the current political transformations and express the conclusion that more holistic evaluation processes should be implemented to perceive the ongoing reformation from wider perspectives.

Keywords: Finland, early childhood education, education reform

\section{Introduction and Policy Overview}

The aim of fluent transition from pre-primary to primary education is to confirm the continuity and integrity of the child's growth and development path. A successful transition requires continuity in values, pedagogy, and institutional structures between institutions. Teachers and other professionals should collaborate and develop the practices which support this continuity. Collaboration between pre-primary and primary education can support successful transitions for children (Rantavuori 2019).

Finnish early childhood education (ECE) policy has been undergoing a reformation since 2013 under the guidance of the Ministry of Education and Culture and as part of the educational system. Previously, early childhood education was considered as a social service mainly determined through social 


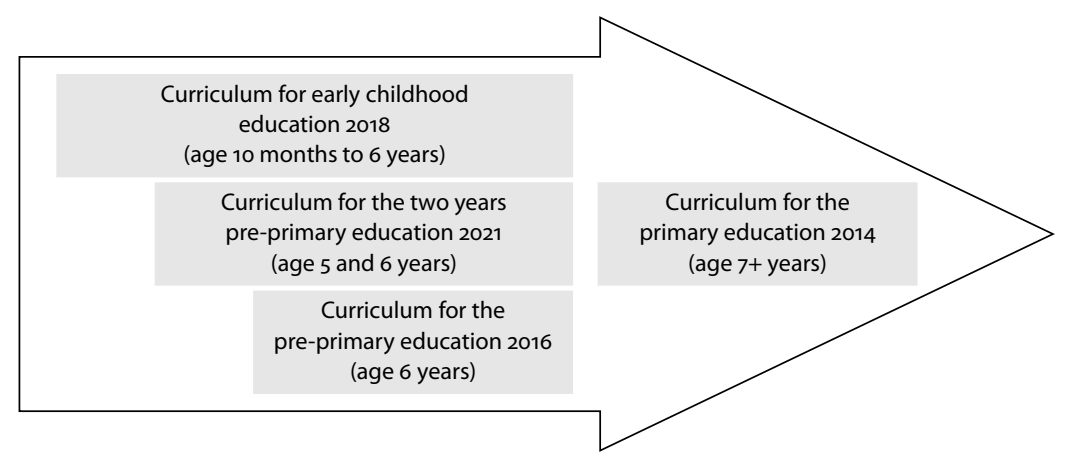

Figure 1 Curricula Considering Education for 10 Months to 9 Years-Old Children in Finland

policies under the Ministry of Social Affairs and Health. With the new placement and role as an important part of the education system, the National Agency for Education became the responsible policy agent for pedagogical control and development (Alila, Ukkonen-Mikkola and Kangas forthcoming). Thus, the pedagogical significance in the educational policies has been emphasised more than before.

The education system and teacher training programmes in Finland have been under reform for the past decade. All policy documents in the field of early childhood education have been renewed and this has influenced both teacher training practices and teachers' work as well. In the year 2015, the old law on childcare was replaced with a law on early childhood education. The new legislation set goals for education, learning, teaching, wellbeing, and the care of children (Alila, Ukkonen-Mikkola and Kangas forthcoming). The next year, the National Agency for Education received a mandate from the Ministry of Education and Culture to create a new curriculum for early childhood education, and not only one, but three different but parallel curricula for the years 1 to 6 which is the considered length of early childhood education in Finland (see figure 1).

Firstly, the reform was completed with the curriculum of pre-primary education in 2016. In Finland, pre-primary education became compulsory for all in 2016, and contains the year between ECE and primary education. Preprimary education is defined through the Act on Basic Education (1998); it has curriculum guidelines (Finnish National Agency for Education 2016) but relies upon the operational culture of ECE through teacher education where preprimary teachers are trained within the ECE teacher education programmes. After the reform of pre-primary education, the curriculum of Early Childhood Education was not only reformed but practically created from scratch be- 
cause there was no current obligatory curriculum existing. The Curriculum Guidelines for Early Childhood Education and Care for 1 to 5 year-old children were published in 2016 and renewed in 2018. The Curriculum Guidelines for Early Childhood Education and Care (Finnish National Agency for Education 2018) set goals for the provision, implementation, and development of ECE. Early childhood education aims to support children's holistic growth, learning, and development with their guardians. The principle is equality and equity among children and the child's participation and active agency in their daily life and society. Finally, after changes in legislation in December 2020, the newest curriculum for piloting two-year pre-primary education for children 5 and 6 years old was published in January 2021 (Finnish National Agency for Education 2021). The two-year pre-primary experiment will be implemented with selected municipalities and a proportion of 5- and 6-yearolds will participate in it.

The role of children in Finnish legislation, education, and guiding documents has also changed during the past decade. The Nordic discourses in childhood especially emphasise the competent and active child, who has perceptions and interests, and who is an active agent of learning and wellbeing in their everyday life (Kangas and Lastikka 2019; Corsaro 2011). In the Nordic curricula, children are seen as active, competent, developing, and learning members of the educational society (Alasuutari, Markström, and Vallberg-Roth 2014). This reflects the viewpoint of sociological research of childhood where children are seen as active agents of their life (Corsaro 2011) and more broadly based on an ontological understanding of childhood and holistic learning (Kangas, Ojala, and Venninen 2015; Liew 2012). Through this whole-child approach, children's rights, especially participation, have become part of ECE and primary education in Finland. Participation is considered as a dynamic and evolving concept of individual and shared competence, rather than a child's property or a stable status quo (Kangas and Reunamo 2019). More generally, participation is related to a contextual social environment and culture of the ECE centre, including interaction, shared meaning-making, and everyday experiences in children's lives (Weckström et al. 2020). The new image of the child and discourse of a competent child in education results in practices where children are pushed to be more active, more competent, and more everything (Kangas and Lastikka 2019).

In this research paper we evaluate the transition process currently taking place in Finnish early childhood education and primary education. We will create an understanding of the political changes within the education field and also review recent researches about the quality of Finnish early educa- 
tion. We discuss the transitions in the educational system as well as the transitions an individual child is experiencing in the educational system. The focus of this research paper is to create an understanding of how these different levels of transitions influence each other and how the holistic educational approach in Finland is organised to support a child's development, learning, and education in general. In our study we consider political documents, curricula, recent research, and reports as our primary data.

This paper draws its ontological viewpoints through the Freirean ideology that people's knowledge about the practices and culture in their field is valuable and therefore they should be considered active agents who can analyse and develop their work (Freire 2000). Dialogical approaches create opportunities to construct the discussion for common perspectives and joint activity (Lyra 2010). The dialogical approach is commonly used to create opportunities for negotiation which in turn strengthen these conceptions about shared items of development and also support reflection about the issues within the topic (Brownlee 2009). In this paper we follow the conclusion of the National Curriculum Guidelines for Early Childhood Education (Finnish National Agency for Education 2018) where the development of educational practices is seen as a dialogic process of all the participants.

The focus of this study is to create an understanding of the ongoing changes and reforms in the Finnish educational system, especially in the context of children's transition from early childhood education to primary school through pre-primary education. We focus on current political alterations, considering the two-year pre-primary education starting on the 1st of August 2021. That is why empirical data from pre-primary education practices are not yet available. In that process a researcher is a facilitator who participates in the development process and respects the participants as owners of their knowledge (see Edwards 2011).

\section{Finnish Education Transformation}

Following the new Act on Early Childhood Education (2018), all policy documents on the field of early childhood education (ECE) have been renewed and this has resulted in a significant change in the operational culture of ECE through content and pedagogical approaches, including the goals of education as well as everyday classroom practices (see Ukkonen-Mikkola and Fonsén 2018; Finnish National Agency for Education 2018). In this new operational culture, teachers are challenged to implement new pedagogical methods to support children in becoming active agents of their learning (HarjuLuukkainen and Kangas 2021). The values of ECE, and further on, primary 
education, are based on international agreements and declarations that ensure the provision of equal access to education and support for all children's growth and learning in the best possible way (United Nations 1989). Children's views should be considered, and their voices should be heard on issues concerning them. The active agency is not only a feature of children and childhood (Corsaro 2011) but also teachers are required to act as active agents in their professional development and learning (Lipponen and Kumpulainen 2011) and throughout their career (see table 1).

The first obligatory version of the National Curriculum Guidelines for Early Childhood Education was published in 2016 and updated in 2018 (Finnish National Agency for Education 2018) as a prescriptive and binding document on the implementation of ECE. Based on the Act and the National Curriculum Guidelines, the National Education Assessment Centre began in 2017 to develop a national evaluation system for the first time in history. At the same time, Finnish ECE research has gained more attention and the quality of research has improved (Alila, Ukkonen-Mikkola and Kangas forthcoming). The newest transition in the field of Finnish education is the new legislation of two years of pre-primary education for 5- and 6-year-old children.

With the new legislation and guiding documents, teachers are challenged to implement pedagogical methods to support children in becoming active agents of their learning. Finnish teachers' competencies and quality of teaching are defined in recent policy documents that introduce the future competencies of teachers, including expertise agency, and innovative approach (Harju-Luukkainen and Kangas 2021). The teachers' increasing responsibilities, together with overwhelming skill sets for the future, are questioned by teacher-trainers in universities as well as by the Teachers Union. The demands for teachers' agency and increasing competencies have been lately critically evaluated and it has been suggested that the large number of different roles given to teachers demand them to be 'more of everything' now and in the future (Harju-Luukkainen and Kangas 2021; Ukkonen-Mikkola and Varpanen 2020).

Finnish early childhood education follows the socio-cultural tradition that understands the role of ECE more holistically and widely. This tradition is used in Nordic countries. The opposite pre-primary tradition represents the idea of ECE to be preparing for school-readiness and is widely used in the UK, US, Belgium, and France (Bennett 2005). In the Nordic pedagogical tradition, the focus of education is to socialise children to their society, and thus participation in ECE is seen as important for the child's development through transversal competencies, learning-to-learn skills through playful learning, 
and participation (see Kangas et al. 2020). The holistic and pedagogy-led tradition has been widely accepted globally. For example, the Australian curriculum for the early years considers learning as a holistic process (see Harju-Luukkainen, Garvis and Kangas 2019), and many European countries have strongly adopted the developmental curriculum tradition focusing on play, holistic development, and learning (European Commission 2014), while the pedagogy can be defined to be 'walking side-by-side' and not so much teaching and showing examples. Teachers focus on scaffolding children through interaction, shared activities, and children's agency (Alila, UkkonenMikkola and Kangas forthcoming).

\section{The Transition between ECE and Primary Education in the Finnish Educational System}

ECE and primary education form an entity that structures consistently concerning the child's learning and growth and builds a foundation for life-long learning. ECE legislation and curricula frame the institutional transitions in Finland. The aim is to secure the continuity and integrity of the child's growth and development path. According to the National Curriculum Guidelines for Early Childhood Education (Finnish National Agency for Education 2018), the personnel of preschools and primary schools are obligated to cooperate during the children's preschool year. In addition, representatives of pre-primary and primary education prepare and develop together the local curriculum for ECE. The personnel and primary school should be familiar with the whole education system and know the goals and practices of its different phases. Additionally, the transition phases need to be planned and evaluated (see Rantavuori 2019). In Finland, all children under school age have the right to high-quality early childhood education (Kangas, Ojala, and Venninen 2015). Early childhood education is organised in class-based programmes, where children participate in under 3 years old groups, 3 to 5 years old groups, or pre-primary classes for children 6 years old. 7 years old and older children participate in primary education with lesson-oriented classes with strong subject-based orientations, and no mixed groups. According to the National Curriculum Guidelines for Early Childhood Education (Finnish National Agency for Education 2018), the local curriculum should determine how cooperation with pre-primary and primary schools is organised. The Act on Early Childhood Education (2018) considered early childhood education to last the first seven years of a child's life. Pre-primary education is, however, organised in a different curriculum only for pre-primary education and the compulsory nature of pre-primary education is regulated in the Act on Primary Education. 
The ECE teacher education programmes are organised at universities, where the teachers for early childhood education are trained as Bachelors of Education and primary school teachers have training for primary education as Masters of Education (see table 1). Both can apply for a diploma qualification for pre-primary education: the ECE teachers qualify automatically as part of their degree, while the primary teachers need to complete an extra study unit of 25 ECTS of pre- and basic education. Basic education refers to the first two grades in primary school.

Personnel and working culture between ECE and primary education is different: professionals of pre-primary education consist of ECE teachers and childminders, but teachers in primary education work alone (see table 1). Multivoiced cooperation and teamwork is part of ECE organisational culture, and this has also been the focus of the development of working culture and practices (Kangas and Ukkonen-Mikkola 2019). Cooperation between education and working life is one central development topic in Finnish ECE. Additionally, the cooperation, professional expertise and division of responsibilities in multi-professional teams should be clarified (Ukkonen-Mikkola, Yliniemi, and Wallin 2020). However, a similar kind of multi-professional working culture is not found in primary education where teachers work mainly alone or with an assistant, although cooperation with other experts, like school psychologists, school health care and pre-primary education, are obligatory (Finnish National Agency for Education 2014).

The environment of ECE is most often a kindergarten, a special ECE centre with a playful learning environment and care facilities (such as napping room, lunch tables in the classes [no cafeterias], room for dressing up, minor sports facilities, and play corners) (Lindberg 2014). Children also have tools, toys, and materials available for their self-initiated activities (Leinonen, Brotherus, and Venninen 2014). The primary education learning environment, considered a classroom with individual or small group desks and other materials than schoolbooks and pencils, are not available for children's selfinitiated use (see table 1). Sports facilities are often located in different buildings and each class has two hours of physical education weekly. Children use the schoolyard for recess time in primary education while in ECE the outdoor activities are part of the everyday pedagogical activities.

Implementation of curricula in early childhood education and primary education is different. In ECE the practices are organised through the Educare approach, where everyday care activities are considered part of the pedagogical planning and implementation (Lager 2019). The organisational culture and practices with children's groups in ECE are organised accordingly, and 
play, exploration, and holistic pedagogies, and children's active agency have been emphasised (Harju-Luukkainen, Garvis, and Kangas 2019). In ECE there are no workbooks or frontal teaching, and most of the activities take place around the classroom, on the floor, standing, moving, or making artwork. Therefore, there are no classes with specific disciplines (such as mathematics or arts) but the subjects are blended in with the project-oriented thematic approach through the phenomenon-based approach (Lonka 2018). Primary education is organised in classes, with frontal teaching, where children focus on mathematics, language, arts, natural science, or sports. Pre-primary education lies between these two traditions (Brotherus 2004). The daily flow is more holistic than in primary education and play and activities are part of everyday learning. In the past decade the discussion has been aiming towards stronger schoolification where children should learn skills necessary for primary school such as concentration, self-regulation, and resilience (Garvis et al. 2019; Kangas, Ojala, and Venninen 2015). The pre-primary classrooms have been organised more like school classes in primary education with personal desks and pen-and-paper activities (Lindberg 2014).

The assessment and evaluation in early childhood education and primary education differ from each other. In pre-primary education children are not graded numerically and they do not receive a school certificate after preprimary education. The assessment is focused on activities and organisations of ECE. The legislation (Act on Early Childhood Education 2018) gives the aim of evaluation work in ECE: 'The purpose of the evaluation of early childhood education and care is to ensure the implementation of the purpose of the Act on Early Childhood Education (2018), support the development of early childhood education and care and promote the conditions for the development, learning and wellbeing of a child. The organiser and provider of ECE shall evaluate the early childhood education and care they provide and participate in external evaluations of their operations. However, different forms of self-evaluations are widely implemented in the practices and teachers document the learning pedagogically and support children to make their learning assessment' (Finnish National Agency for Education 2018).

In primary education the pupil assessment plays a significant role in promoting the learning of the pupils. High-quality assessment is an essential part of the learning process. The core curriculum (Finnish National Agency for Education 2018) provides the criteria of performance for assessment. The learning outcomes evaluation is based on objectives defined in the preprimary and primary education core curricula. Additionally, pupils are encouraged to reflect on their learning in relation to their objectives through 
self-evaluation. The aim is that the pupils recognise themselves as life-long learners. Student assessment in primary education is based on continuous assessment. In Finland, no school rankings based on student performance exist. This supports teachers' considerable freedom in planning pedagogical activities and assessment of student learning (Salokangas and Kauko 2015). Teachers are allowed to design various and multiple assessment methods. In primary education there is an evaluation of students' progress after each semester with a report card indicating performance in academic and nonacademic subjects, and behaviour and engagement (Sahlberg 2015).

In Finland, the Finnish Education Evaluation Centre (FINEEC) draws up recommendations and guidelines for evaluating the quality of ECE. The municipalities and Regional Administrative State Agencies (AVIs) are jointly responsible for overseeing the implementation of all ECE programmes in their area (Act on Early Childhood Education 2018; Finnish National Agency for Education 2018). In primary school there is also external assessment. Regular national assessments are carried out by the FINECC using sample-based methodology including about 10 percent of an age cohort (Finnish Education Evaluation Centre n.d.) (see table 1).

\section{Case Examples of Transition Practices}

In most municipalities, clear practices have been created for cooperation in pre-primary and primary education. In this section we present three different case examples of how the transition of children from pre-primary education to primary education is supported through cooperation between ECE centres and schools. These cases are traditional cooperation between the ECE centre and school, kindergarten school (päiväkotikoulu), and class-based preprimary-basic practice (alkuluokka).

Traditional cooperation between pre-primary and primary education is implemented through regular collaborative meetings with pre-primary and primary school teachers. Additionally, the curricula are developed together with teachers. In these cases, kindergarten and school are located in separate buildings. Even in these cases pre-primary and primary school pupils are regularly involved in joint activities, like common workshops (see Kuntaliitto 2020). The challenges concerning this kind of collaboration can be that children move to different schools after pre-primary education, e.g. from one pre-primary unit children can start their school in four primary schools because of the school district boundaries. These kinds of challenges are encountered especially in the countryside.

Kindergarten schools are becoming more popular in Finland. This means 
Table 1 Early Childhood Education (with Pre-Primary) and Primary Education System in Finland

\begin{tabular}{|c|c|}
\hline $\begin{array}{l}\text { Ministry responsible for ECE } \\
\text { and primary education }\end{array}$ & Ministry of Education and Culture \\
\hline Key legislation & $\begin{array}{l}\text { ECE: Act on Early Childhood Education (2018). } \\
\text { Primary: Act on Primary Education (which contains the organ- } \\
\text { isation of pre-primary education). }\end{array}$ \\
\hline Curricula & $\begin{array}{l}\text { ECE: National Curriculum Guidelines for Early Childhood Educa- } \\
\text { tion (2018). } \\
\text { ECE: National Core Curriculum for Pre-Primary Education } \\
\text { (2016). } \\
\text { Primary: National Core Curriculum for Basic Education (2014) }\end{array}$ \\
\hline Qualifications of personnel & $\begin{array}{l}\text { ECE teachers: Bachelor's degree with automatic qualifications } \\
\text { to pre-primary education. } \\
\text { Working in multi-professional cooperation with childminders: } \\
\text { three years of upper secondary school. } \\
\text { Primary school teacher: Master's degree, qualification to pre- } \\
\text { primary education through special study unit. }\end{array}$ \\
\hline Environment & $\begin{array}{l}\text { ECE: Kindergartens (as homely environment). } \\
\text { Pre-primary education: Mostly kindergartens, also within } \\
\text { school classes. } \\
\text { Primary: Schools. }\end{array}$ \\
\hline Professional development & $\begin{array}{l}\text { ECE: Five days per school year. The employer ensures teach- } \\
\text { ers' participation in in-service teacher training. } \\
\text { Pedagogical development is part of the organisational cul- } \\
\text { ture in early childhood education (including pre-primary } \\
\text { classes) and the responsibility of teachers. } \\
\text { Primary: Five days per school year. The employer ensures } \\
\text { teachers' participation in in-service teacher training. }\end{array}$ \\
\hline Educator-to-child ratio & $\begin{array}{l}\text { ECE: 1:7 for children over } 3 \text { years (pre-primary full-day class). } \\
\text { ECE: 1:13 children of } 6 \text { years (pre-primary half-day class). } \\
\text { Primary: No ratio by law in primary education. }\end{array}$ \\
\hline Compulsory/voluntary & $\begin{array}{l}\text { ECE: Years } 1 \text { to } 5 \text { Voluntary. } \\
\text { ECE: Year } 6 \text {, so-called pre-primary, Compulsory pre-primary } \\
\text { class. } \\
\text { Primary: Compulsory. }\end{array}$ \\
\hline $\begin{array}{l}\text { Children start formal } \\
\text { education }\end{array}$ & $\begin{array}{l}6 \text { years (pre-primary education). } \\
7 \text { years (primary education, until } 16 \text { years). }\end{array}$ \\
\hline Assessment and evaluation & $\begin{array}{l}\text { ECE: Assessment focus on activities and organisation. } \\
\text { Primary: Assessment focus on pupils' learning. }\end{array}$ \\
\hline
\end{tabular}

that early childhood education (years $1-5$ ), pre-primary (6 years) and primary education are implemented in the same building. Pupils work mainly in their classes, but cooperation between classes is natural and happens daily. 
Teachers can design and implement common curricula, workshops, and activities easily. The benefits are that pupils get familiar with primary school teachers and premises, e.g. classrooms, dining room, and gym. Additionally, it makes possible the flexible utilisation of the learning environment considering the change of the age structure and regional need (e.g. 'Kangasvuoren päiväkotikoulu' n.d.).

Pre-primary-basic activities are the planned daily work of pre-primary and primary education in a common learning environment, normally in a shared classroom. The class includes some pupils who are studying in pre-primary education and some following the first and/or second-grade curriculum. The class is staffed by an ECE teacher and a primary teacher, and, if necessary, by an assistant. Small group activities are used every day by teachers able to offer age-specific learning assignments for each student. The benefits of this system are that pupils do not have to move to other buildings during the day, and the child will continue in the first and second class with familiar teachers and children. Additionally, children can participate flexibly in the different levels of activities ('Alkuluokkatoiminta' n.d.).

\section{Conclusion}

In Finland, research is limited to the comparison of different ways of implementing transitions, although some principles about good practices concerning transitions are recognised. Karila and Rantavuori (2014) highlight the cooperation between pre-primary and primary school teachers. They recognised in their study the collaborative frame of co-operation as a starting point of successful co-operation. This frame emphasises relational agency, which involves valuing and recognising the motives and resources of other professionals (see Edwards 2011). This way, the development of shared activities is possible. In addition, Rantavuori (2018) points out the meaning of teachers' shared knowledge when solving problems concerning transitions. This is possible when pre-primary and primary school teachers work actively and persistently. As a whole, the cultures of pre-primary and primary education can be different, and continuing research and development work for fluent transitions is needed (Karila and Rantavuori 2014).

To understand the quality aspect of early childhood education it is important to understand the curricular and political traditions behind the education practices. International research identifies two different traditions of early childhood education (Bennett 2005). The pre-primary tradition represents the idea of early education to be preparing school readiness through 'schoolification' and is widely used in the UK, US, Belgium, and France. The 
other tradition, the so-called socio pedagogical or developmental tradition used in Nordic countries, understands the role of early childhood education and care more holistically and widely. In this curricular tradition the participation in education is understood as essential for holistic development through transversal competencies, learning-to-learn skills, and play (see Kangas et al. 2020). The curriculum tradition focusing strongly on school readiness has received critical reviews. For example, Wood and Hedges (2016) claim that considering the positioning either from pedagogical or developmental psychology points of view the coherence of the curriculum is seen from opposite ways. Bodrova (2008), following the Vygotskyan tradition, raises a warning about defining learning through cognitive outputs which causes the time and space for play, imagination, and holistic learning to be reduced. In Early Childhood Education and Care the Nordic countries follow a holistic and developmental-led curricular tradition where the focus is to support children's overall growth, development, learning, wellbeing, and agency (Finnish National Agency for Education 2018; Kangas, Ojala, and Venninen 2015; Bennett 2005). The Nordic countries have also imported ideas, methods, and philosophies from other countries following the school-readiness tradition and have aimed to develop their educational sector through national projects and policies during the past decade. In the Nordic perspective these are closely linked to national and global economies as well as transnational cultural ideas and ideals (see also Garvis et al. 2019). During the last decade we have seen a large increase in studies indicating the importance of the early years. In Finland this has led to a discussion on how to enhance the quality of early learning environments and who should be the responsible party to lead and supervise this development.

In the year 2015, the Finnish Education Evaluation Centre (FINEEC) took charge of the quality development of Early Childhood Education. However, in literature, there is little consensus on how to define high quality and further, how to develop it. Quality is a complex concept with many interdependent variables, which all are influencing the practices in Early Childhood Education (European Commission 2014). Several analyses of these guidelines show that the Nordic countries are struggling with uniting the concepts of care, upbringing, and education, also known as Educare (Lager 2019). It is important to focus on the transformation and enactment of national objectives through a more critical and reflective method and a more democratic view of educational evaluation in Nordic countries' highly decentralised systems (Vallberg-Roth 2014). In Finland the discussion culminated in the Finnish Education Evaluation Centre's recently published guidelines and recommen- 
dations for evaluating the quality of early childhood education and care in Finland (Vlasov et al. 2019). The goal of this policy document was to define more closely how quality is and should be seen in Finnish ECE. The purpose of the document was to support service providers in carrying out systematic and goal-oriented self-evaluation associated with quality management and to provide tools for evaluating the structure and content of early childhood education and care.

However, one year later, FINEEC implemented research about the schoolreadiness of six-year-old children entering primary education (see Ukkola and Metsamuuronen 2019). The results were used to set a new law of preprimary education: with increasing length and new curriculum, this new preprimary education is drawing its goals from the UK pre-primary traditions (Act on a Two-year Pre-Primary Education 2020). It seems that despite the legislation and focus of Early Childhood Education in Finland the quality indicators are used to transform the Finnish education system towards the schoolreadiness discourse.

Children's views on pre-primary and primary education have not been often studied. However, some findings exist. Kangas and Lastikka (2019) showed in their research about children's initiatives that children in ECE do not refer to their everyday activities and experiences as 'learning.' However, the pre-primary class children referred in interviews to their new role as students whose role is to learn about new knowledge and things. Children also considered that play and playing is something that is part of ECE and sometimes also pre-primary education, but not anymore in primary school (Brotherus 2004). In more recent research children have considered their role in the evaluation and assessment processes vague and the meaning of these processes quite unclear. For example, Pihlainen et al. (2019) showed how evaluation processes completed with children were considered ineffective and frustrating by both children and teachers. On the other hand, Rantavuori (2019) has stated that when professionals form multi-professional teams for the benefit of children, children are not participating in any of these meetings.

Lembrér and Johansson (2016) discuss the tension in the pre-primary environment that exists between the child as being or child as becoming. Within the Swedish pre-primary curriculum, they have been finding conflict with the increasing practices of schoolification. While the tradition represents the holistic Nordic model of early childhood education, the changing curriculum is pushing the teachers to focus on teaching to develop children's understanding or skills that they do not currently possess. In other words, only 
seeing them as becoming. This means that there are fewer opportunities for children to demonstrate their existing understandings and skills and experience participation and agency, in other words, be treated as beings. However, the Swedish pre-primary education curriculum does present opportunities where both being and becoming can co-exist even though the teachers do not necessarily enact these opportunities to become eventuated (see Lembrér and Meaney 2014). In Nordic countries and more broadly globally, researchers have expressed their worries concerning schoolification and too early implementation of formal teaching and learning practices (see Garvis, Harju-Luukkainen, and Yngvesson 2019). Bodrova (2008), following the Vygotskyan tradition, raises a warning about defining learning through cognitive outputs which causes the time and space for play, imagination, and holistic learning to be reduced. Urban (2017) expresses strong statements against test-driven evaluation and global scoring that does not consider cultural context or children's participation and involvement. If more assessment and evaluation is needed, efficient approaches could include using adequate and age-appropriate methods to foster children's participation and listen to children's views (cf. Kangas and Reunamo 2019), concerns and ideas and take these into account in the assessment process (cf. Pihlainen et al. 2020), and implementing existing tools to improve the inclusiveness of early childhood education provision.

When aiming to improve and develop the transitions in education in the future, the discussion at the political and practical level should consider the values and focuses of the education. If the question 'Who are children and what is their role in education?' remains unanswered and children's participation is not fully implemented in the educational system, it is impossible to develop the transition processes in Finnish education. We posit that risks of current political transformation are schoolification, and test-driven education. Because the concept of learning in Finnish early childhood education is based on holistic learning through play, activities and expression, a profound evaluation process is needed concerning the changing pre-primary education.

\section{References}

Act on Basic Education. 1998. https://www.finlex.fi/fi/laki/ajantasa/1998/ 19980628?search\%5Btype\%5D=pika\&search\%5Bpika\%5D $=$ perusopetuslaki.

Act on Early Childhood Education. 2018. https://www.finlex.fi/fi/laki/ kaannokset/2018/en20180540.pdf. 
Act on Two-Year Pre-primary Education. 2020. https://www.finlex.fi/en/laki/ kaannokset/2020/en20201046.

Alasuutari, M., A. Markström, and A. Vallberg-Roth. 2014. Assessment and Documentation in Early Childhood Education. Abington: Routledge.

'Alkuluokkatoiminta.' N.d. Hollola. https://www.hollola.fi/alkuluokkatoiminta.

Alila, K., T. Ukkonen-Mikkola, and J. Kangas. Forthcoming. 'Elements of the Pedagogical Process in Finnish Early Childhood Education.' In Finnish Early Childhood Education and Care: From Research to Policy and Practice, edited by H. Harju-Luukkainen, J. Kangas, and S. Garvis. Basingstoke: Springer.

Bennett, J. 2005. 'Curriculum Issues in National Policy-Making.' European Early Childhood Education Research Journal 13 (2): 3-23.

Bodrova, E. 2008. 'Make-Believe Play versus Academic Skills: A Vygotskian Approach to Today's Dilemma of Early Childhood Education.' European Early Childhood Education Research Journal 16 (3): 357-369.

Brotherus, A. 2004. 'Esiopetuksen toimintakulttuuri lapsen näkökulmasta.' PhD diss., University of Helsinki.

Brownlee, J. 2009. 'Context, Pedagogy and Participatory Learning.' In Participatory Learning in the Early Years: Research and Pedagogy, edited by J. Berthelsen, J. Brownlee, and E. Johansson, 203-208. New York: Routledge.

Corsaro, W. A. 2011. The Sociology of Childhood. 3rd ed. Los Angeles, CA: Sage.

Edwards, A. 2011. 'Building Common Knowledge at the Boundaries between Professional Practices: Relational Agency and Relational Expertise in Systems of Distributed Expertise.' International Journal of Educational Research 50 (1): 33-39.

European Commission. 2014. 'Proposal for Key Principles of a Quality Framework for Early Childhood Education and Care.' Brussels: European Commission.

Finnish Education Evaluation Centre. N.d. 'Pre-Primary and Basic Education.' https://karvi.fi/en/pre-primary-and-basic-education/.

Finnish National Agency for Education. 2014. National Core Curriculum for Basic Education. Helsinki: Finnish National Agency for Education.

- 2016. The National Core Curriculum for Pre-Primary Education. Helsinki: Finnish National Agency for Education.

- 2018. National Core Curriculum for Early Childhood Education. Helsinki: Finnish National Agency for Education.

- 2021. National Core Curriculum for Two-Year Pre-Primary Education. Helsinki: Finnish National Agency for Education.

Freire, P. 2000. Pedagogy of the Oppressed. London: Bloomsbury.

Garvis, S., H. Harju-Luukkainen, and T. Yngvesson. 2019. 'Towards a Test-Driven Early Childhood Education: Alternative Practices to Testing Children.' In Compassion and Empathy in Educational Contexts, edited by G. Barton and S. Garvis, 61-77. Cham: Palgrave Macmillan. 
Garvis, S., H. Harju-Luukkainen, S. Sheridan, and P. Williams, eds. 2019. Nordic Families, Children and Early Childhood Education. Cham: Palgrave Macmillan.

Harju-Luukkainen, H., and J. Kangas. 2021. 'The Role of Early Childhood Teachers in Finnish Policy Documents: Training Teachers for the Future?' In International Perspectives on Early Childhood Teacher Education in the 21st Century, edited by S. Philippson and S. Garvis. London: Springer Nature.

Harju-Luukkainen, H., S. Garvis, and J. Kangas. 2019. 'After Lunch We Offer Quiet Time and Meditation: Early Learning Environments in Australia and Finland through the Lenses of Educators.' In Globalization, Transformation, and Cultures in Early Childhood Education and Care, edited by S. Faasand and $\mathrm{H}$. Wasmuth, 203-219. Cham: Palgrave Macmillan.

Kangas, J., and H. Harju-Luukkainen. 2021. 'What Is the Future of ECE Teacher Profession? Teacher's Agency in Finland through the Lenses of Policy Documents.' The Morning Watch: Educational and Social Analysis 47 (1): 59-75.

Kangas, J., and A.-L. Lastikka. 2019. 'Children's Initiatives in the Finnish Early Childhood Education Context.' In Nordic Families, Children and Early Childhood Education, edited by S. Garvis and H. Harju-Luukkainen, 15-36. Cham: Palgrave Macmillan.

Kangas, J., and J. Reunamo. 2019. 'Action Telling Method: From Storytelling to Crafting the Future.' In Story in Children's Lives: Contributions of the Narrative Mode to Early Childhood Development, Literacy, and Learning, edited by K. J. Kerry-Moran and J.-A. Aerila, 146-164. New York: Springer.

Kangas, J., and T. Ukkonen-Mikkola, 2019. 'Multi-Voiced Development in Finnish Early Childhood Education Practices.' International Journal of Learning, Teaching and Educational Research 18 (11): 1-17.

Kangas, J., M. Ojala, and T. Venninen. 2015. 'Children's Self-Regulation in the Context of Participatory Pedagogy in Early Childhood Education.' Early Education and Development 26 (5-6): 847-870.

Kangas, J., H. Harju-Luukkainen, A. Brotherus, L. Gearon, and A. Kuusisto. 2020. 'Outlining Play and Playful Learning in Finland and Brazil: A Content Analysis of Early Childhood Education Policy Documents.' Contemporary Issues in Early Childhood. https://doi.org/10.1177/1463949120966104.

'Kangasvuoren päiväkotikoulu.' N.d. Jyväskylä. https://www.jyvaskyla.fi/ varhaiskasvatus/varhaiskasvatusjyvaskylassa/paivakodit/huhtasuo/ kangasvuori.

Karila, K., and R. Rantavuori. 2014. 'Discourses at the Boundary Spaces: Developing a Fluent Transition from Preschool to School.' Early Years 34 (4): 377-391.

Kuntaliitto. 2020. Esi-ja alkuopetuksen yhteistyö kunnissa:Selvitys esi-ja alkuopetuksen yhteistyöstä kunnissa. Helsinki: Suomen Kuntaliitto.

Lager, K., 2019. 'Systematic Quality Work in a Swedish Context.' In Nordic Families, Children and Early Childhood Education, edited by S. Garvis, H. Harju- 
Luukkainen, S. Sheridan, and P. Williams, 173-192. Cham: Palgrave Macmillan.

Leinonen, J., A. Brotherus, and T. Venninen, 2014. 'Children's Participation in Finnish Pre-School Education: Identifying, Describing and Documenting Children's Participation.' Nordisk Barnehageforskning 7 (8): 1-16.

Lembrér, D., and M. C. Johansson. 2016. 'Swedish Preschool Teachers' Views of Children's Socialisation.' Paper presented at the 13th International Congress on Mathematical Education, Hamburg, Germany, July 24-31.

Lembrér, D., and T. Meaney. 2014. 'Socialisation Tensions in the Swedish PreSchool Curriculum: The Case of Mathematics.' In EDUCARE 2014:4 Childhood, Learning and Didactics, edited by I. Bergman, N. Ericsson, L. Hartsmar, C. Lang, T. Ljungberg, I. Småberg, and J. Söderman, 89-106. Malmö: Malmö Högskola.

Liew, J. 2012. 'Effortful Control, Executive Functions, and Education: Bringing Self-Regulatory and Social-Emotional Competencies to the Table.' Child Development Perspectives 6 (2): 105-111.

Lindberg, P. 2014. 'In Search of Affordances and Visual Quality.' PhD dissertation, University of Oulu.

Lipponen, L., and K. Kumpulainen, 2011. 'Acting as Accountable Authors: Creating Interactional Spaces for Agency Work in Teacher Education.' Teaching and Teacher Education 27 (5): 812-819.

Lonka, K., ed. 2018. Phenomenal Learning from Finland. Edita: Helsinki.

Lyra, M. C. 2010. 'On Interaction Analysis and Dialogical Perspective: Emergent Patterns of Order and Relational Agency.' Integrative Psychological and Behavioral Science 44 (3): 273-280.

Pihlainen, K., J. Reunamo, N. Sajaniemi, and E. Kärnä. 2020. 'Children's Negative Experiences as a Part of Quality Evaluation in Early Childhood Education and Care.' Early Child Development and Care. https://doi.org/10.1080/ 03004430.2020 .1801667$.

Rantavuori, L. 2018. 'Towards a Relational Expertise in Flexible Pre- and Primary Education.' PhD dissertation, University of Tampere.

- 2019. 'The Problem-Solving Process as Part of Professionals' Boundary Work in Preschool to School Transition.' International Journal of Early Years Education 26 (4): 422-435.

Sahlberg, P. 2015. Finnish Lessons: What Can the World Learn from Educational Change in Finland? New York: Teachers College Press.

Salokangas, M., and J. Kauko. 2015. 'Borrowing Finnish PISA Success? Critical Reflections from the Perspective of the Lender.' Educação e Pesquisa 41:13531364.

Ukkonen-Mikkola, T., and E. Fonsén. 2018. 'Researching Finnish Early Childhood Teachers' Pedagogical Work Using Layder's Research Map.' Australasian Journal of Early Childhood 43 (4): 48-56. 
Ukkonen-Mikkola, T., and J. Varpanen. 2020. 'Integrated Initial and Continuing Training as a Way of Developing Teachers' and Student Teachers' Professional Agency.' Teaching and Teacher Education 96: 103189. https://doi.org/ 10.1016/j.tate.2020.103189.

Ukkonen-Mikkola, T., R. Yliniemi, and O. Wallin. 2020. 'Varhaiskasvatus muuttuu - muuttuuko asiantuntijuus?' Työelämän tutkimus-lehti 18 (4): 323-339.

Urban, M. 2017. 'We Need Meaningful, Systemic Evaluation, Not a Preschool PISA.' Global Education Review 4 (2): 18-24.

United Nations. 1989. 'Convention on the Rights of a Child.' https://www.ohchr .org/en/professionalinterest/pages/crc.aspx.

Vallberg-Roth, A. C. 2014. 'Nordic Comparative Analysis of Guidelines for Quality and Content in Early Childhood Education.' Journal of Nordic Research in Early Childhood Educational Research 8 (1): 1-30.

Vlasov, J., J. Salminen, L. Repo, K. Karila, S. Kinnunen, V. Mattila, T. Nukarinen, S. Parrila, and H. Sulonen. 2019. Guidelines and Recommendations for Evaluating the Quality of Early Childhood Education and Care. Publications 5:2019. Helsinki: Finnish Education Evaluation Centre.

Weckström, E., L. Karlsson, S. Pöllänen, and A. L. Lastikka. 2020. 'Creating a Culture of Participation: Early Childhood Education and Care Educators in the Face of Change.' Children \& Society 35 (4): 503-518.

Wood, E., and H. Hedges. 2016. 'Curriculum in Early Childhood Education: Critical Questions about Content, Coherence, And Control.' The Curriculum Journal 27 (3): 387-405.

\section{Spreminjanje prehajanja iz predšolskega v osnovnošolsko izobraževanje na Finskem}

Finska politika predšolskega izobraževanja (ECE) se od leta 2013 pod vodstvom ministrstva za izobraževanje in kulturo in kot del izobraževalnega sistema spreminja. Tako je pedagoški vidik v izobraževalnih politikah bolj poudarjen kot prej. Najnovejša reforma v avgustu 2021 začenja z dvoletnim predšolskim izobraževanjem. S tem se postopek prehoda iz predšolskega $v$ osnovnošolsko izobraževanje na Finskem razširja na štiri leta otrokovega življenja - od petega do osmega leta starosti. $V$ tej študiji preučujemo proces prehoda z vidika izobraževanja in kvalifikacij učiteljev, organizacijske in delovne kulture, učnega okolja, izvajanja učnega načrta ter spremljanja in ocenjevanja. Izpostavljamo nevarnost pošolanja in na testiranju utemeljeno, osredotočeno izobraževanje, kar vodi trenutne politične transformacije, ter zaključujemo, da bi bilo treba implementirati celostnejše evalvacijske procese za dojemanje reforme s širših perspektiv.

Ključne besede: Finska, predšolska vzgoja, izobraževalna reforma 